\title{
Mikrostruktura i własności złączy ze stali 7CrMoVTiB10-10 uzyskanych w procesie spawania laserowego
}

\author{
Microstructure and properties of laser welded joints \\ of 7CrMoVTiB10-10 steel
}

\section{Streszczenie}

Celem pracy była analiza struktury, zmian składu chemicznego oraz twardości złączy jednoimiennych ze stali 7CrMoVTiB10-10 uzyskanych w wyniku spawania wiązką lasera $\mathrm{CO}_{2}$, poddanych obróbce cieplnej - wyżarzaniu w temperaturze $755^{\circ} \mathrm{C}$ przez $0,5 \mathrm{~h}, 1 \mathrm{~h}$ oraz $2 \mathrm{~h}$. Badania mikroskopowe przeprowadzono za pomocą: mikroskopii świetlnej i elektronowej skaningowej. Materiał badawczy poddano jakościowej i ilościowej analizie składu chemicznego stosując technikę EDS, której celem było określenie rozkładu poszczególnych pierwiastków w złączu i w ujawnionych wydzieleniach. Ponadto określono zmiany twardości na przekroju złączy. Badania wykazały uzyskanie złączy o jednorodnym składzie chemicznym. Wykazano występowanie w złączach wydzieleń bogatych w tytan, mangan, wanad. Twardość w spoinie wynosiła ok. 400 HV1, a w SWC ok. 360 HV1. Zastosowanie obróbki cieplnej spowodowało spadek twardości spoiny do ok. 270 HV1.

Słowa kluczowe: spawanie laserowe; stal bainityczna; obróbka cieplna; 7CrMoVTiB10-10

\begin{abstract}
The paper presents results of the microstructure investigation, changes of chemical composition and hardness of the 7CrMoVTiB10-10 steel joints and their analyzes after heat treatment at $755^{\circ} \mathrm{C}$ for $0.5 \mathrm{~h}, 1 \mathrm{~h}, 2 \mathrm{~h}$. The joints were performed with a $\mathrm{CO}_{2}$ laser. Microstructural research where carried out using light and scanning electron microscopy. The energy dispersive spectroscopy was applied to specify distribution of chemical elements in the welded joints and revealed precipitates. Moreover the hardness tests were determined in order to define change of hardness at the cross-section of the joints. Investigation shown homogenous chemical composition in the welds. In the joints the precipitates rich in $\mathrm{Ti}, \mathrm{Mn}$, and $\mathrm{V}$ were revealed. Hardness of the weld amounted $400 \mathrm{HV} 1$, but of HAZ - $360 \mathrm{HV} 1$. Heat treatment led to decreasing of the hardness of laser joints to about $270 \mathrm{HV} 1$.
\end{abstract}

Keywords: laser welding; bainitic steel; heat treatment; 7CrMoVTiB10-10

\section{Wstęp}

Rosnące zapotrzebowanie na energię elektryczną wymusza ciągły rozwój sektora energetycznego. Rozwój ten następuje głównie poprzez budowę coraz nowszych bloków energetycznych o większej sprawności i mniejszej emisji zanieczyszczeń. Zwiększenie sprawności można uzyskać poprzez nowsze rozwiązania konstrukcyjne, jednak osiągany przyrost sprawności jest niewystarczający. Zatem wzrost sprawności bloków energetycznych uzyskuje się poprzez podnoszenie parametrów pary takich jak ciśnienie i temperatura. Jednak, aby to było możliwe konieczne jest opracowywanie coraz nowszych materiałów i metod ich łączenia. Stosowane wówczas materiały pracują w warunkach pełzania, przy podwyższonej temperaturze i ciśnieniu w warunkach nadkrytycznych. Stal 7CrMoVTiB10-10 (T24) jest niskostopową chromowo-molibdenowo-wanadową stalą, przeznaczoną na elementy kotłów energetycznych m.in. na: elementy ścian membranowych, rury przegrzewaczy pary $[1 \div 7]$. Charakteryzuje się występowaniem struktury bainitycznej lub bainityczno-martenzytycznej z niewielką ilością ferrytu oraz z wydzieleniami węglików $\mathrm{M}_{23}(\mathrm{C}, \mathrm{B})_{6}$ i $\mathrm{Mo}_{2} \mathrm{C}$. Dodatek wanadu, boru i tytanu prowadzi do tworzenia wydzieleń typu $\mathrm{MX}(\mathrm{M}=\mathrm{V}, \mathrm{Ti}, \mathrm{B}$; $\mathrm{X}=\mathrm{C}, \mathrm{N}$ ) i MC, które zwiększają odporność na pełzanie $[1,3]$. Jednocześnie tytan jest pierwiastkiem o dużym powinowactwie do tlenu [8]. Kolejnym aspektem jest wprowadzenie niewielkich ilości boru stabilizującego bainit w podwyższonej temperaturze [8]. Zawartość węgla utrzymana na niskim poziomie poprawia spawalność oraz teoretycznie umożliwia spawanie bez podgrzewania.

Mgr inż. Olaf Czyż, dr inż. Agnieszka Radziszewska - AGH Akademia Górniczo-Hutnicza.

Autor korespondencyjny/Corresponding author. olafczyz@agh.edu.pl 
W procesach technologicznych wytwarzania elementów konstrukcyjnych kotłów z przedstawionej stali napotyka się na szereg trudności związanych z występowaniem pęknięć w złączach spawalnych $[2,6]$. Zatem konieczny jest dobór materiałów oraz technik ich łączenia, prowadzący do uzyskania złączy pozbawionych niezgodności spawalniczych. Jedną z nowocześniejszych metod jest laserowe spawanie umożliwiające m.in. precyzyjne skupienie wiązki na określonym obszarze elementu, ograniczenie szerokości strefy wpływu ciepła, małe odkształcenie złączy, stosowanie dużych prędkości przemieszczania wiązki prowadzące do większej efektywności procesu łączenia.

Przedmiotem pracy jest analiza mikrostruktury i właściwości złączy ze stali 7CrMoVTiB10-10 uzyskanych w procesie spawania laserowego.

\section{Materiał i metodyka badań}

Materiał badań stanowiły rury z niskostopowej stali bainitycznej 7CrMoVTiB10-10 (T24) o średnicy 48,5 mm i grubości ścianki 4,63 mm. W tablicy I przedstawiono skład chemiczny stali 7CrMoVTiB10-10. Laserowe spawanie wykonano za pomocą lasera TRUMPF LASERCELL 1100 (TLC 1005) $\mathrm{CO}_{2}$ o mocy $6 \mathrm{~kW}$. Zastosowano wiązkę dwuogniskową oraz osłonę gazową, którą stanowił He z $3 \%$ dodatkiem $\mathrm{O}_{2}$ podawany z natężeniem przepływu $20 \mathrm{l} / \mathrm{min}$. Prędkość obrotowa rur podczas przetapiania laserem wynosiła $8 \mathrm{obr} / \mathrm{min}$. Z zespawanych doczołowo rur pobrano próbki do badań mikrostruktury, składu chemicznego i twardości. Zgłady poddano trawieniu stosując odczynnik o składzie: $5 \mathrm{~g} \mathrm{FeCl}_{3}, 4 \mathrm{ml} \mathrm{HCl}, 90 \mathrm{ml} \mathrm{CH} \mathrm{CH}_{3} \mathrm{OH}$.

Ocenę mikrostruktury złączy przeprowadzono za pomocą mikroskopu świetlnego (MŚ) Axio Imager M1 m firmy Carl Zeiss oraz skaningowego mikroskopu elektronowego (SEM) FEI Inspect S50. W celu przeprowadzenia analizy składu chemicznego na zgładach metalograficznych zastosowano spektrografię promieniowania rentgenowskiego z dyspersją energii (EDS), spektrometrem firmy EDAX. Wykonano analizy ilościowe, których celem było określenie zmian zawartości pierwiastków w obszarach złącza oraz powstałych wydzieleniach. Analiza obejmowała podstawowe pierwiastki wchodzące w skład materiału dostarczonego: Cr, Mo, Mn, V, Ti, Si. W stosowanej analizie ilościowej zastosowano normalizację do $100 \%$ zawartości analizowanych pierwiastków. W celu określenia zmian twardości złączy wykonano badania za pomocą twardościomierza TUKON 2100 (Wolpert-Wilson) firmy Instron przy obciążeniu 9,8 N. Pomiary przeprowadzono wzdłuż linii równoległej do powierzchni lica i grani spoiny oddalonych od nich o $1 \mathrm{~mm}$. W każdym przypadku badania rozpoczynano w materiale podłoża, kontynuując kolejno w strefie wpływu ciepła, spoinie, strefie wpływu ciepła i kończąc po stronie przeciwległej spoiny w materiale wyjściowym. Uzyskane złącza laserowe poddano obróbce cieplnej - wyżarzaniu w temp. $755^{\circ} \mathrm{C}$ przy różnych czasach: $0,5 \mathrm{~h}, 1 \mathrm{~h}$ oraz $\mathrm{h}$, $\mathrm{z}$ wolnym chłodzeniem w powietrzu.

Tablica I. Skład chemiczny stali 7CrMoVTiB10-10, \% mas. wg PN-EN 10216-2:2014-02 [9]

Table I. Chemical composition of 7CrMoVTiB10-10 steel, \% mas. PN-EN 10216-2:2014-02 [9]

\begin{tabular}{|c|c|c|c|}
\hline C & Si & Mn & Cr \\
\hline $0,05 \div 0,1$ & $0,15 \div 0,45$ & $0,3 \div 0,7$ & $2,2 \div 2,6$ \\
\hline Mo & V & Ti & B \\
\hline $0,9 \div 1,1$ & $0,2 \div 0,3$ & $0,05 \div 0,1$ & $0,0015 \div 0,007$ \\
\hline
\end{tabular}

\section{Wyniki badań}

Mikrostrukturę stali 7CrMoVTiB10-10 w stanie dostarczonym przedstawiono na rysunku 1. Obserwacja mikrostruktury wykazała, że materiał rodzimy charakteryzuje się występowaniem struktury odpuszczonego bainitu i martenzytu (rys. 1 i 2) [10,11]. W obszarze granic ziaren byłego austenitu i listew bainitu obserwowano wydzielenia, które cechowały się różnymi rozmiarami (od ok. 0,1 $\mu \mathrm{m}$ do ok. 1,5 $\mu \mathrm{m}$ ) i drobnodyspersyjnym rozkładem wewnątrz ziaren (rys. 2).

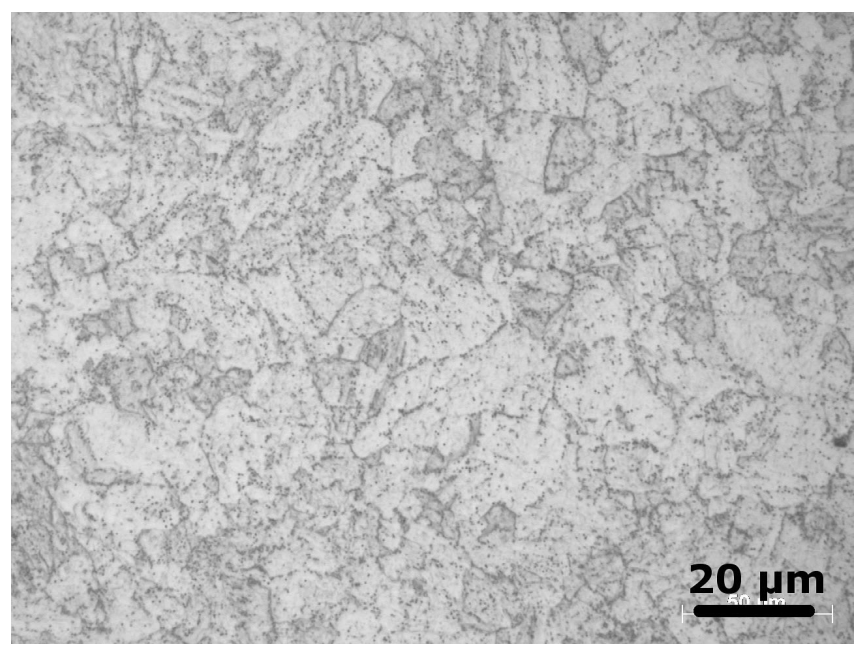

Rys. 1. Mikrostruktura stali 7CrMoVTiB10-10 w stanie dostarczonym Fig. 1. Microstructure of 7CrMoVTiB10-10 steel in delivery condition

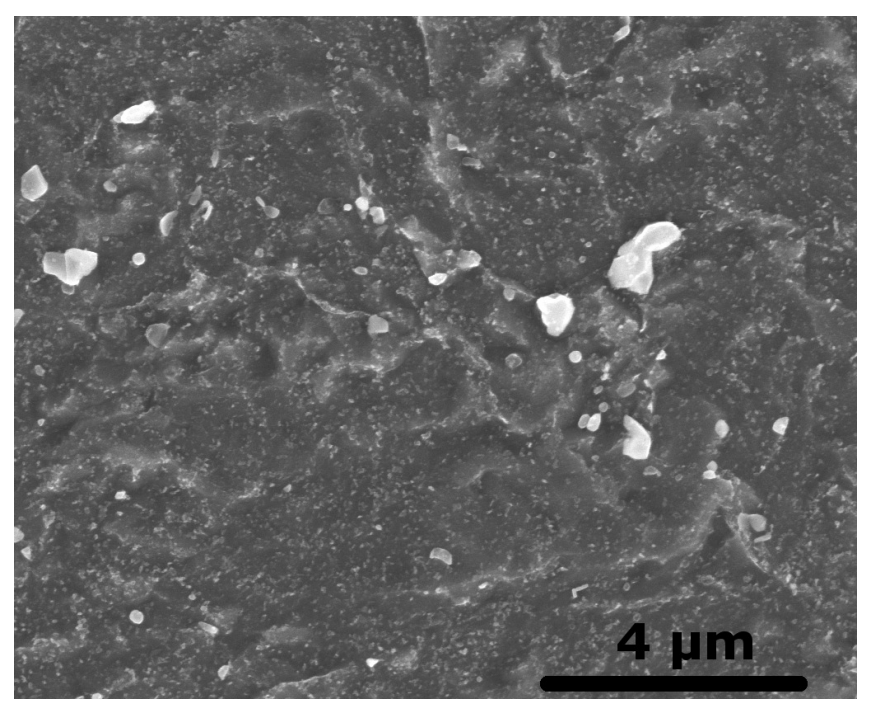

Rys. 2. Obraz SEM obszaru materiału rodzimego (stal 7CrMoVTiB10-10) Fig. 2. SEM image of base material (7CrMoVTiB10-10 steel)

W wyniku spawania laserowego powstały następujące strefy złącza: spoina, strefa wpływu ciepła (SWC) oraz materiał rodzimy (MR) (rys. 3). Spoina w obszarze lica miała szerokość $3,4 \mathrm{~mm}$, natomiast w obszarze grani $1 \mathrm{~mm}$. W wyniku kierunkowego odprowadzania ciepła z krzepnącego jeziorka, powstała wąska strefa ciepła sięgającą od ok. 0,7 mm do ok. 0,9 mm. Wstępne badania wizualne dotyczące kontroli obecności porowatości, pęknięć w spoinie i w strefie wpływu ciepła oraz ultradźwiękowe i penetracyjne wykazały, że w złączach nie występują niezgodności spawalnicze.

Analiza struktur po krzepnięciu wskazuje, że krystalizacja spoiny rozpoczynała się strefą o drobnokrystalicznej strukturze (rys. 4b), przechodząc w kryształy ułożone kolumnowo (rys. $4 a$ ), pod kątem od $17^{\circ}$ do $45^{\circ} \mathrm{w}$ stosunku do osi spoiny. W spoinie występował bainit z martenzytem o twardości ok. $400 \mathrm{HV} 1$. 


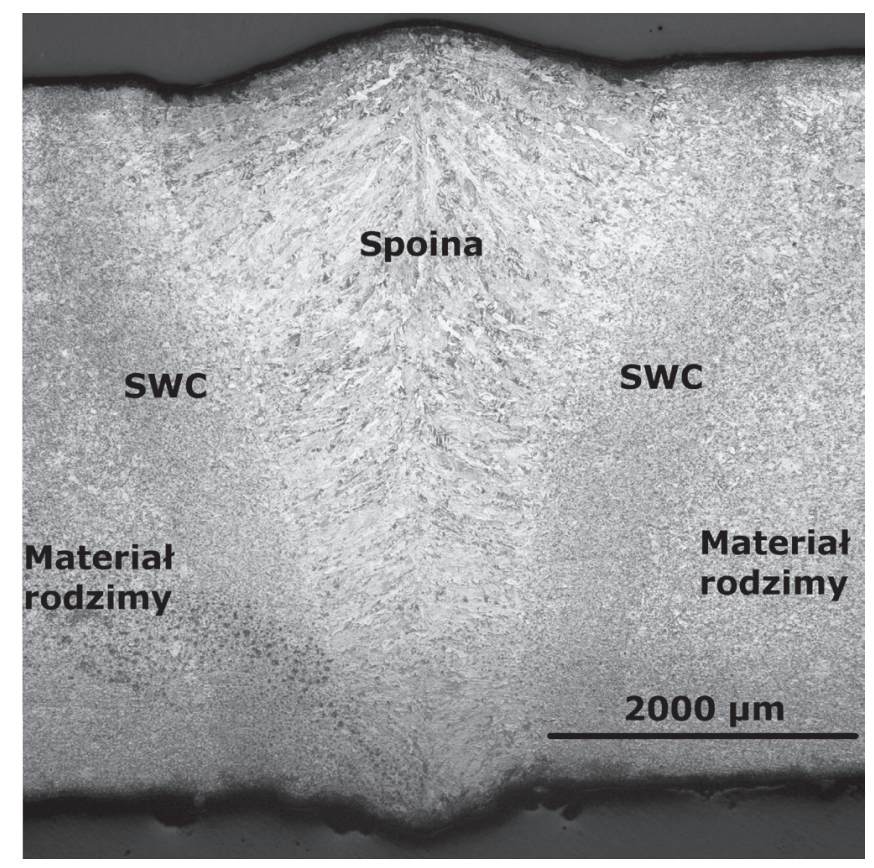

Rys. 3. Obraz mikroskopowy obszarów powstałych w złączu spawanym stali 7CrMoVTiB10-10

Fig. 3. Light microscopy image of area in welded joint of 7CrMoVTiB10-10 steel

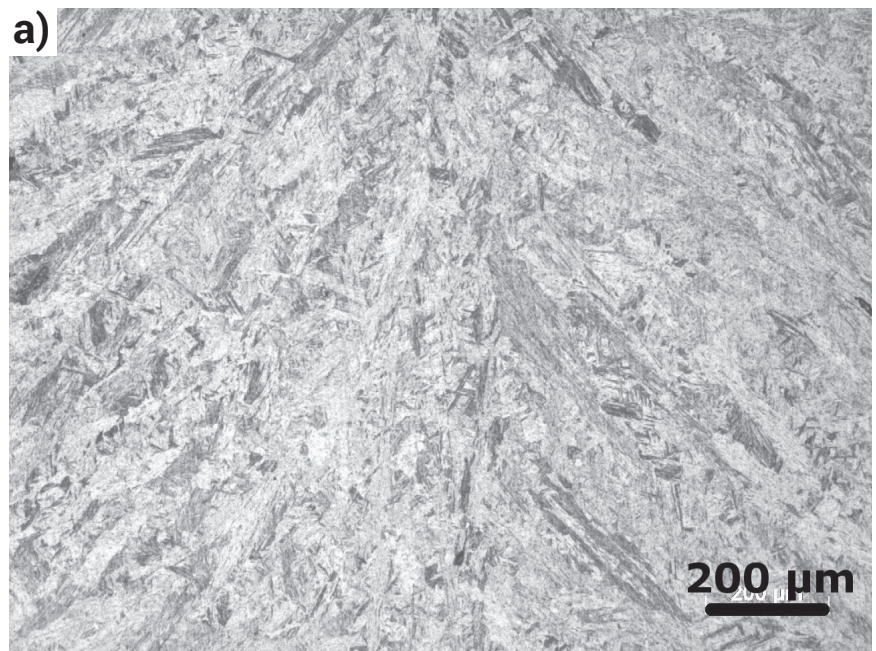

W obszarze strefy wpływu ciepła nagrzanej do temperatury z zakresu $\mathrm{Ac}_{1} \div \mathrm{Ac}_{3}\left(815 \div 960{ }^{\circ} \mathrm{C}\right)$ powstał obszar częściowego przekrystalizowania. Część ziaren uległa wysokiemu odpuszczeniu, a część przemianie bainitu w austenit, który w trakcie chłodzenia utworzył bainit. Obserwacje mikroskopowe potwierdziły występowanie w SWC wysokoodpuszczonego bainitu oraz martenzytu (rys. 5 a i $5 b$ ). Podobne struktury uzyskano również w przypadku spawania tej stali łukiem krytym [7].

Ilościowa analiza składu chemicznego poszczególnych obszarów złącza (przy licu, w środku i grani spoiny oraz w SWC) i materiału rodzimego wykazała, że zawartość pierwiastków takich jak krzem, chrom, molibden, wanad i mangan są porównywalne (rys. 6). Świadczy to o jednorodności składu chemicznego w różnych obszarach złącza i pozwala wykluczyć makrosegregacje. Mikroanaliza składu chemicznego wykonana dla wydzieleń występujących w materiale rodzimym wykazała, że są one bogate w chrom (10,7\% mas.), molibden ( $4,5 \%$ mas.), mangan ( $1,7 \%$ mas.) i wanad ( $0,7 \%$ mas.). Z kolei wydzielenia obserwowane w spoinie charakteryzowały się występowaniem tytanu ( $8,9 \%$ mas.), manganu $(2,6 \%$ mas), wanadu (0,9\% mas.) i krzemu (0,8\% mas.) (rys. 7). Świadczy to o występowaniu węglików/węglikoazotków tych pierwiastków.

Rys. 4. Obraz mikroskopowy: a) spoiny, b) i SWC uzyskanych w wyniku laserowego spawania stali 7CrMoVTiB10-10

Fig. 4. Light microscopy image of: a) weld material, b) and HAZ obtained as the result of 7CrMoVTiB10-10 steel
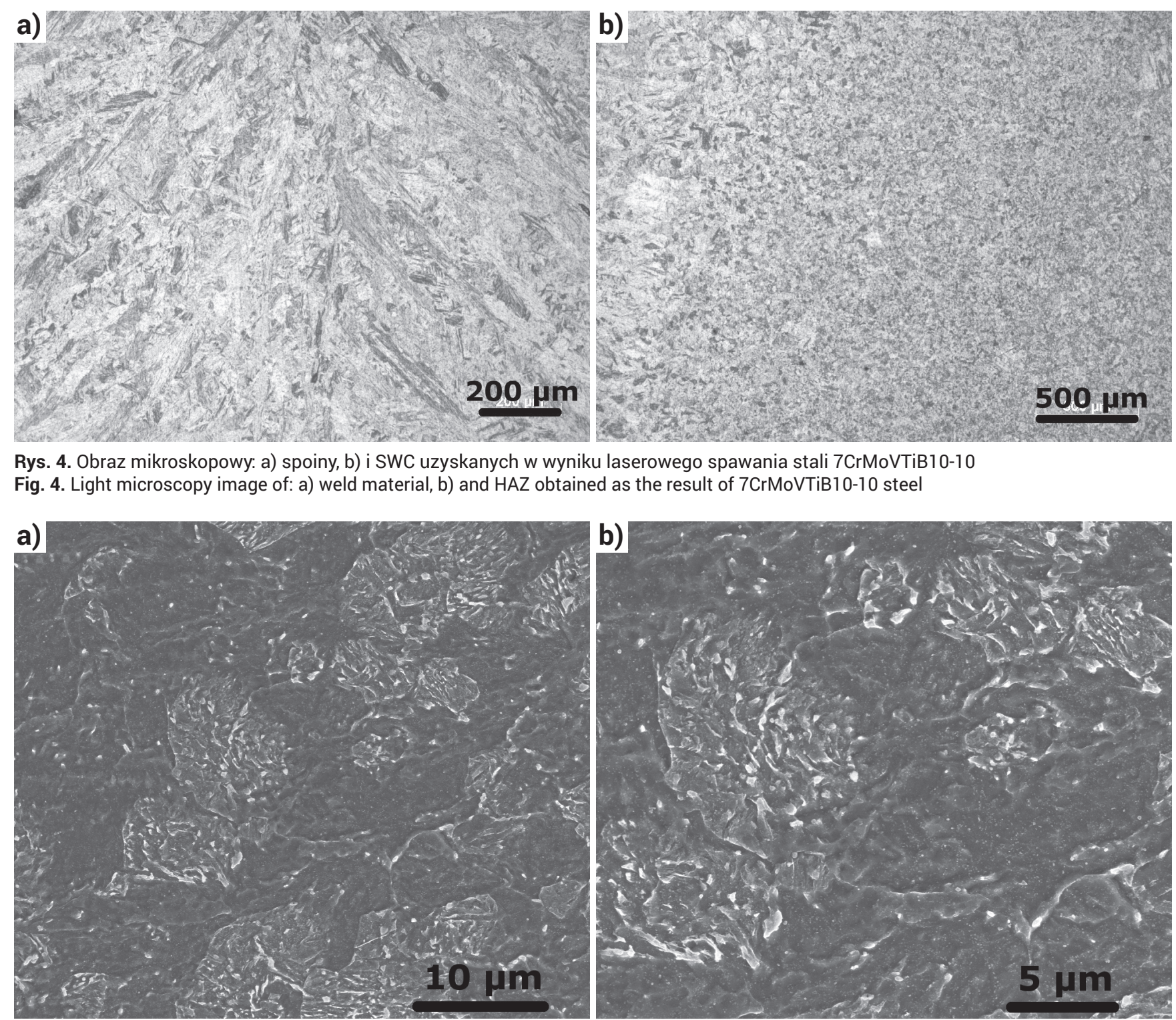

Rys. 5. Obrazy SEM obszaru częściowego przekrystalizowania występującego w strefie wpływu ciepła

Fig. 5. SEM image of intercritical heat affected zone 


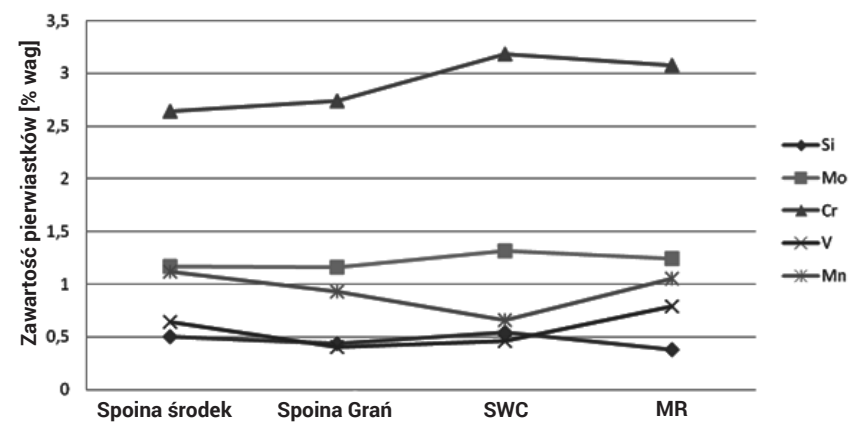

Rys. 6. Rozkład zmian składu chemicznego $\mathrm{Si}, \mathrm{Mo}, \mathrm{Cr}, \mathrm{V}$ i $\mathrm{Mn}$ w poszególnych obszarach złącza oraz w materiale rodzimym (MR); SWC - strefa wpływu ciepła

Fig. 6. Chemical elements distributions of $\mathrm{Si}, \mathrm{Mo}, \mathrm{Cr}, \mathrm{V}$ and $\mathrm{Mn}$ in selected areas of welded joint and base material

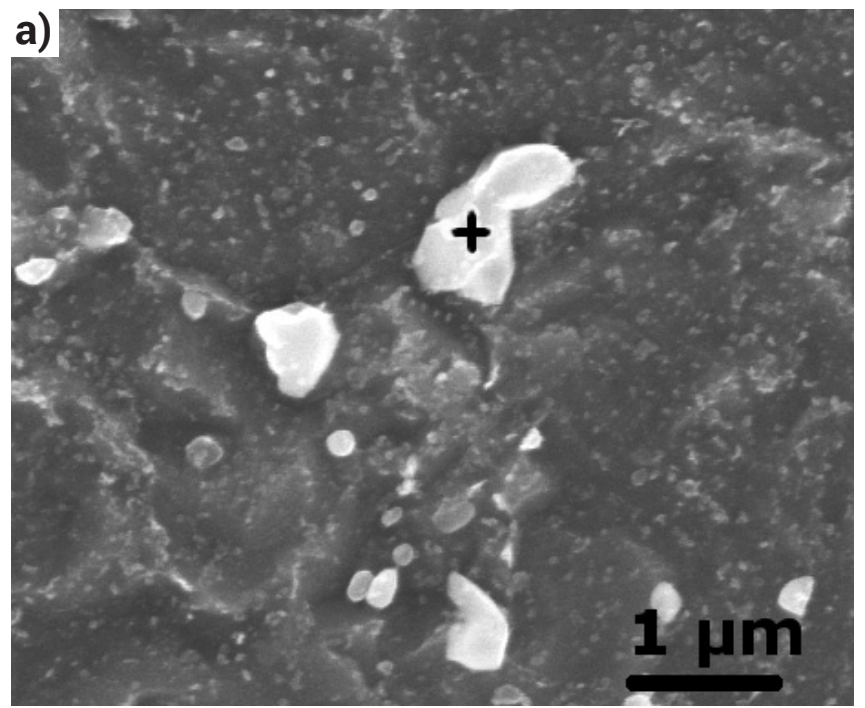

Zmiany twardości złącza w funkcji odległości od osi spoiny przedstawiono na rysunku 8 . Pomiary wykazały porównywalne wartości twardości poszczególnych stref występujących przy licu i grani spoiny. Twardość wzrastała w obszarze spoiny i sięgała ok. 400 HV1. W SWC nastąpił spadek twardości od ok. 360 HV1, osiągając 220 HV1 w materiale rodzimym.

\section{Obróbka cieplna}

W wyniku spawania w spoinie osiągnięto twardość powyżej 400 HV1, co przekracza kryterium odbiorowe dla złączy spawanych, wynoszące 350 HV1. Otrzymana struktura złączy spawanych laserowo oraz podwyższona twardość

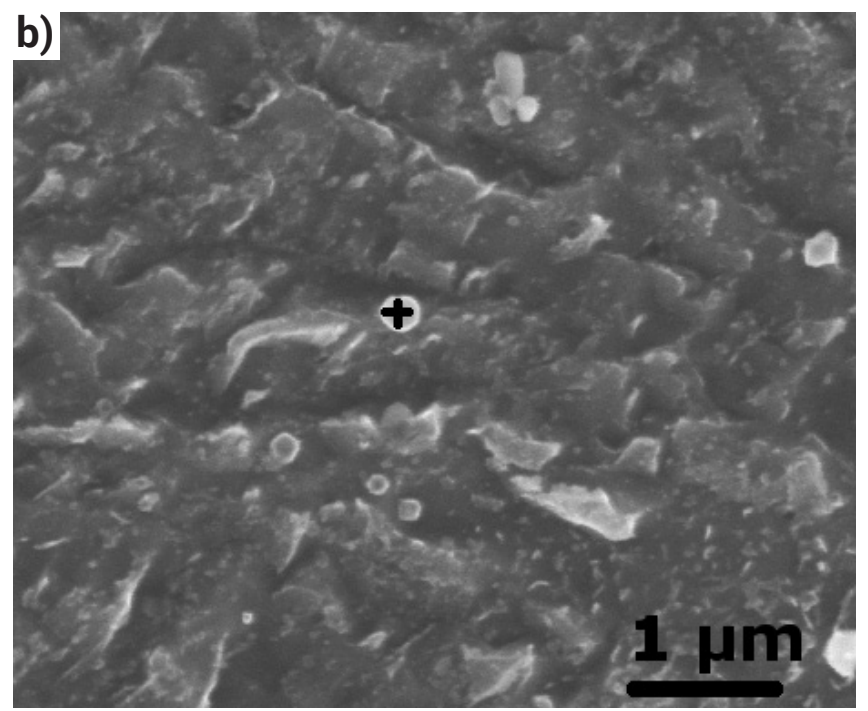

Rys. 7. Analiza składu chemicznego cząstek: a) w obszarze materiału rodzimego, b) w obszarze spoiny Fig. 7. Chemical composition analysis from particles: a) in base material, b) in weld material

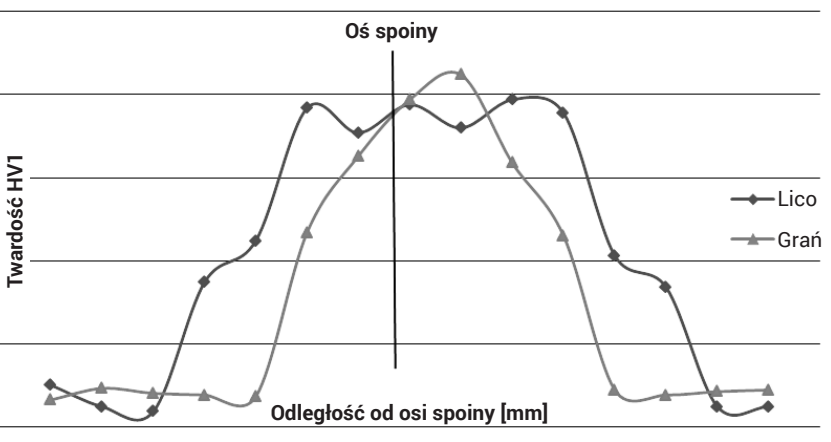

Rys. 8. Wykres zmiany twardości złącza w funkcji odległości od osi spoiny ze stali 7 CrMoVTiB10-10. Pomiary wykonano przy licu i grani spoiny Fig. 8. Hardness distribution as the function of the distance from the joint axis of welded joint of $7 \mathrm{CrMoVTiB} 10-10$ steel. The measurements were carried out at the weld face and the root of joint spoiny i SWC, jak również konieczność spełnienia kryteria odbioru złączy, wymaga przeprowadzenia obróbki cieplnej mającej na celu zapobieganie pękaniu złączy. Występowanie pęknięć w złączu jest wynikiem obniżenia zdolności do odkształceń, jak również wysokiego stanu naprężeń wewnętrznych. Próbki poddano wyżarzaniu w temperaturze $755^{\circ} \mathrm{C}$. Dla określenia jak wpływa czas obróbki cieplnej na zmianę twardość złączy zastosowano następujące czasy: 0,5h, 1h i $2 \mathrm{~h}$. Obniżenie temperatury wyżarzania poniżej $730^{\circ} \mathrm{C}$ może spowodować występowanie twardości wtórnej, jak również obniżenie udarności będącej wynikiem przemiany austenitu szczątkowego w bainit i przesycony ferryt. Na rysunku 9 przedstawiono obraz mikroskopowy spoiny po obróbce cieplnej. Złącze to było pozbawione mikropęknięć i nieciągłości, a wydzielenia występujące na granicach ziaren były większe niż obserwowane w ich wnętrzach (rys. 10).

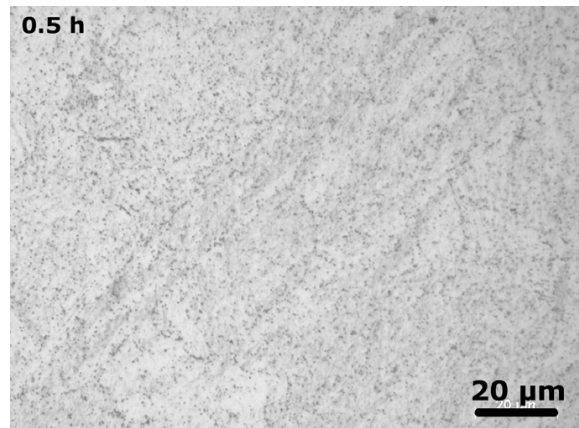

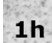

1h

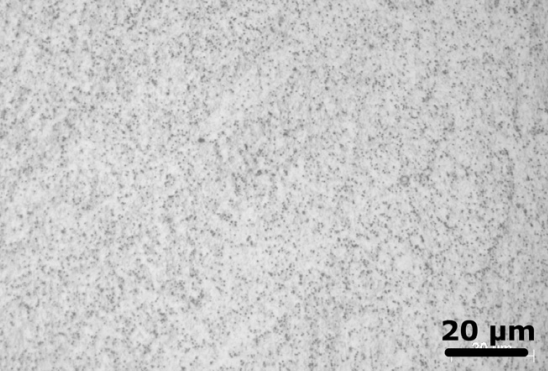

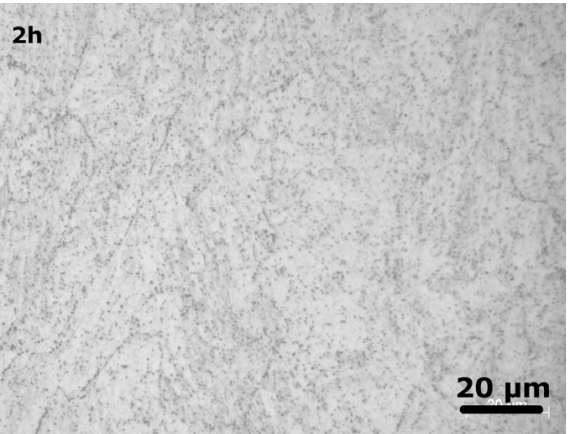

Rys. 9. Obraz mikroskopowy spoiny poddanej obróbce cieplnej, temperatura $755^{\circ} \mathrm{C}$, różny czas: $0,5 \mathrm{~h}, 1 \mathrm{~h} \mathrm{i} 2 \mathrm{~h}$

Fig. 9. Light microscopy image of weld material after heat treatment at $755^{\circ} \mathrm{C}$, in different time: $0,5 \mathrm{~h}, 1 \mathrm{~h}$ i $2 \mathrm{~h}$ 

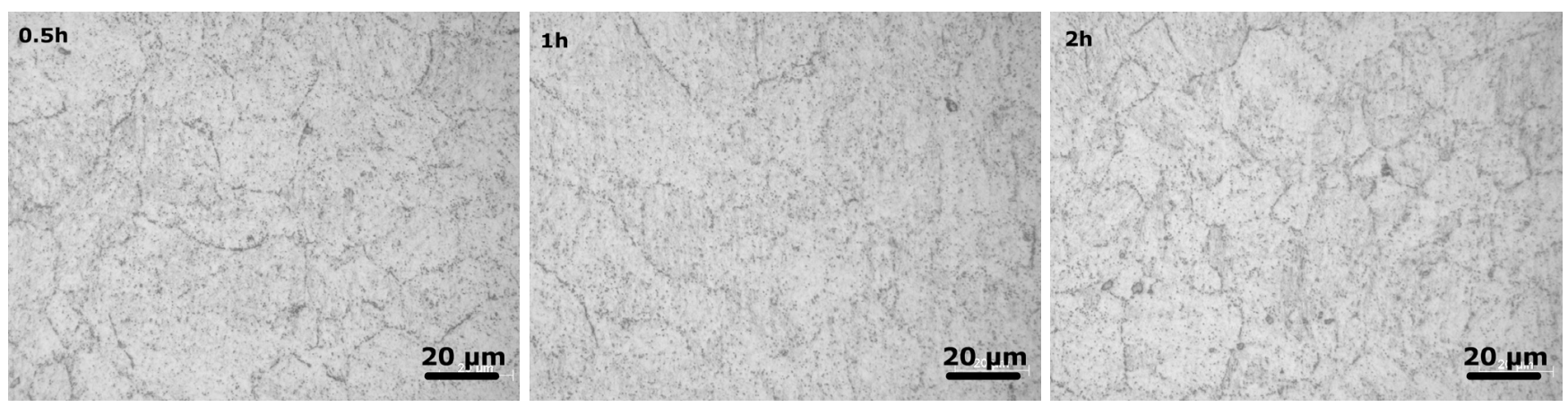

Rys. 10. Mikrofotografie strefy wpływu ciepła poddanej obróbce cieplnej, temperatura $755^{\circ} \mathrm{C}$, różny czas: $0,5 \mathrm{~h}, 1 \mathrm{~h}$ i $2 \mathrm{~h}$

Fig. 10. Light microscopy image of the heat affected zone after heat treatment at $755^{\circ} \mathrm{C}$, in different time: $0,5 \mathrm{~h}, 1 \mathrm{~h} \mathrm{i} 2 \mathrm{~h}$

Po odpuszczaniu nastąpił spadek twardości złącza (rys. 11). Po czasie odpuszczania 0,5h twardość wynosiła ok. 270 HV1, która w pełni spełnia wymagany poziom kryteriów dopuszczenia złączy. Wraz ze wzrostem czasu odpuszczania następował dalszy spadek twardości. Po $2 \mathrm{~h}$ odpuszczania spoina miała twardość ok. 250 HV1.

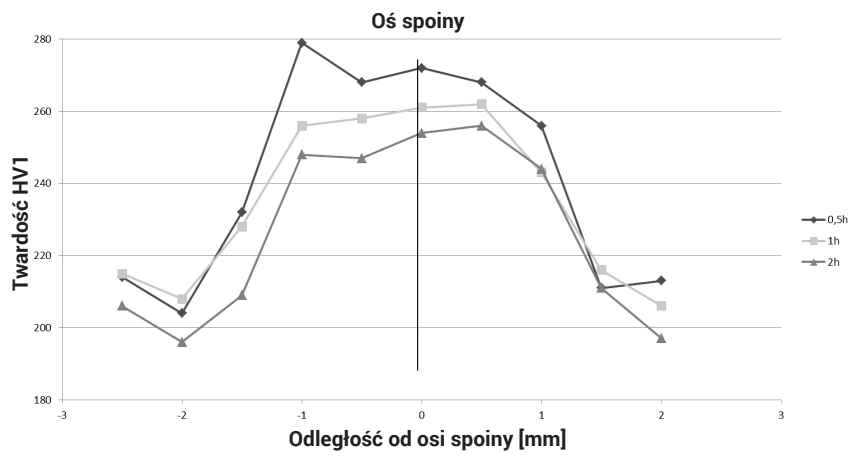

Rys. 11. Wykres zmiany twardości złącza w funkcji odległości od osi spoiny poddanego obróbce cieplnej $\mathrm{w}$ temperaturze $755^{\circ} \mathrm{C}$ przez $0,5 \mathrm{~h}, 1 \mathrm{~h}$ i $2 \mathrm{~h}$

Fig. 11. Hardness distribution as the function of the distance from the joint axis of welded joint after heat treatment at $755^{\circ} \mathrm{C}$, in different time: $0,5 \mathrm{~h}, 1 \mathrm{~h}$ i $2 \mathrm{~h}$

\section{Wnioski}

Przeprowadzone badania wykazały, że odpowiedni dobór parametrów spawania laserowego stali 7CrMoVTiB10-10 pozwolił uzyskać jednorodne złącza pozbawione niezgodności spawalniczych. Mikroanaliza składu chemicznego spoiny wykazała jednorodny rozkład pierwiastków, tj. Cr, Ti, Mo, Mn w poszczególnych obszarach złącza. Spoina charakteryzowała się strukturą bainityczną z martenzytem, w której obserwowano wydzielenia o podwyższonej zawartości Ti, Mn, V i Si, a w materiale rodzimym w Cr, Mo, Mn i V. Twardość spoiny po laserowym spawaniu wynosiła 400 HV1, a strefy wpływu ciepła ok. 360 HV1. Zastosowanie obróbki cieplnej złącza doprowadziło do obniżenia twardości spoiny do ok. 270 HV1 i strefy wpływu ciepła do ok. 250 HV1. Konieczne jest zatem przeprowadzenie obróbki cieplnej złączy ze stali 7CrMoVTiB10-10 otrzymanych w procesie spawania laserowego.

Badania wykonano w ramach projektu Las-Energ: Technologie laserowego spawania dla energetyki i ochrony środowiska, umowa z NCBiR: nr PBS1/B5/13/2012 z dn. 12.12.2012 r. Autorzy pragną podziękować Prof. dr hab. inż. W. Zowczakowi i Prof. dr hab. inż. B. Antoszewskiemu za udostępnienie próbek do badań i przeprowadzenie spawania laserowego.

\section{Literatura}

[1] Hernas A., Dobrzański J., Pasternak J., Fudali S.: Charakterystyki nowej generacji materiałów dla energetyki, Wydawnictwo Politechniki Śląskiej, Gliwice, 2015.

[2] Pańcikiewicz K., Tasak E.: Charakter pękania połączeń spawanych stali 7CrMoVTiB10-10 (T24), Przegląd Spawalnictwa, vol. 85 (2), s. 36-39, 2013.

[3] Golański G., Kępa J.: Nowoczesne stale dla energetyki - charakterystyka, Wydawnictwo Politechniki Częstochowskiej, Częstochowa 2011.

[4] Pańcikiewicz K., Kwiecień S., Tasak E.: Właściwości połączeń spawanych stali bainitycznej 7CrMoVTiB10-10, Przegląd Spawalnictwa, vol. 82 (10), s. 8-14, 2010.

[5] Zieliński A., Golański G., Sroka M.: Influence of long-term ageing on the microstructure and mechanical properties of T24 steel, Materials Science and Engineering, vol. 682, s. 664-672, 2017.

[6] Ziewiec A., Pańcikiewicz K., Tasak E.: Pękanie spoin w stali 7CrMoVTiB10-10 (T24) w czasie spawania, uruchamiania i eksploatacji bloków energetycznych, Przegląd Spawalnictwa, vol. 84 (5), s. 2-7, 2012.
[7] Pańcikiewicz K., Zielińska-Lipiec A., Tasak E.: Mikrostruktura i właściwości mechaniczne złączy stali T24 spawanych metodami konwencjonalnymi i wysokoenergetycznymi, Przegląd Spawalnictwa, vol. 86 (4), s. 5-10, 2014.

[8] Dimic A., Bakic G.M., Djukic M.B., Sijacki Zeravcic V., Ristivojevic M.: Characterization of welded joint made of T24 steel (7CrMoVTiB10-10) with and without post-weld heat treatment, 3rd IIW South-East European Welding Congress, Welding and Joining Technologies for a Sustainable Development and Environment, Timisoara, Romania, s. 185-189, 2015.

[9] PN-EN 10216-2:2014-02. Rury stalowe bez szwu do zastosowań ciśnieniowych - Warunki techniczne dostawy - Część 2: Rury ze stali niestopowych i stopowych z określonymi własnościami w temperaturze podwyższonej.

[10] Pańcikiewicz K., Zielińska-Lipiec A.: TEM investigations of the microstructure of 7CrMoVTiB10-10 steel weld metal, Solid State Phenomena, vol. 231, s. 101-106, 2015.

[11] Ziewiec A., Parzych S., Tasak E.: Skłonność do pęknięć zimnych stali bainitycznej stosowanej w podwyższonych temperaturach, HutnikWiadomości Hutnicze, 78, s. 978-981, 2011. 